\title{
Reconceptualising product life-cycle theory as stakeholder engagement with non-profit organisation
}

Article

Accepted Version

Mitchell, S.-L. and Clark, M. (2019) Reconceptualising product life-cycle theory as stakeholder engagement with non-profit organisation. Journal of Marketing Management, 35 (1-2). pp. 13-39. ISSN 1472-1376 doi:

https://doi.org/10.1080/0267257X.2018.1562487 Available at https://centaur.reading.ac.uk/81464/

It is advisable to refer to the publisher's version if you intend to cite from the work. See Guidance on citing.

To link to this article DOI: http://dx.doi.org/10.1080/0267257X.2018.1562487

Publisher: Taylor \& Francis

All outputs in CentAUR are protected by Intellectual Property Rights law, including copyright law. Copyright and IPR is retained by the creators or other copyright holders. Terms and conditions for use of this material are defined in the End User Agreement.

www.reading.ac.uk/centaur 
Central Archive at the University of Reading

Reading's research outputs online 
Paper Title: Reconceptualising Product Life-Cycle Theory as Customer Engagement with Non-Profit Organisations.

\section{Authors:}

Dr. Sarah-Louise Mitchell (corresponding author), Oxford Brookes University, Headington Road, Oxford, OX3 0BP, UK.

Professor Moira Clark, Henley Business School, Greenlands, Henley-on-Thames, RG9 3AU, UK.

Contact details for corresponding author: smitchell@brookes.ac.uk, +44 (0)1235762384.

Acknowledgements: The authors would like to thank the reviewers of the Journal of Marketing Management and the Academy of Marketing Conference (UK, July 2017) for their supportive and constructive feedback on earlier versions of this paper. Also, thanks go to Dr. Gary Bess for sharing his original 1998 paper. 


\title{
Reconceptualising Product Life-Cycle Theory as Stakeholder Engagement with Non-Profit Organisations.
}

\begin{abstract}
The paper critically re-examines product life-cycle (PLC) theory, developed over fifty years ago. Despite prevalence in marketing pedagogy and continued popularity within empirical research, PLC is seldom challenged. The paper identifies the organisation-centric construct underpinning the theory and highlights a disconnection between PLC theory and the recent academic insight around customer engagement.
\end{abstract}

It reconceptualises the life-cycle concept based on engagement between stakeholder and non-profit organisation (NPO), structured upon both the market orientation and social exchange constructs. The revised framework maps stakeholder engagement with the NPO through the five stages of incubation, interaction, involvement, immersion, and incapacitation. The paper concludes with identifying a roadmap for future empirical research to develop and validate the re-envisaged conceptual model. The methodology used is narrative literature review supported by secondary research from specialist practitioner reports.

Key words: Theory, Market Orientation, Not for Profit Marketing, Customer Engagement, Product Life-Cycle Theory

Summary statement of contribution: The paper envisages new ideas through revising an existing concept, that of the ubiquitous life-cycle theory. It identifies a disconnection between the organisationcentric construct of the original theory and recent developments in academic research with respect to stakeholder engagement. It presents the reconceptualisation of life-cycle theory as stakeholder engagement through a specific exemplar, the non-profit sector. 


\section{Introduction}

The metaphor of biological growth within marketing theory is alive and kicking. Exemplified by the popular product life-cycle (PLC), new product development is charted from birth through growth to maturity and death. Developed as a theoretical concept over fifty years ago (Levitt, 1965; Vernon, 1966), it remains widely used in marketing research (Delre, Broekhuizen, \& Bijmolt, 2016; Zhang, Han, Liu, Liu, \& Leng, 2015) despite occasional critics (Dhalla \& Yuspeh, 1976; Moon, 2005).

For managers, understanding the dynamics of products, services, brands and organisations ensures they remain competitive through changing market conditions, utilising appropriate investment and strategy. Life-cycle models can provide a conceptual roadmap to inform responses to critical organisational transitions (Phelps, Adams, \& Bessant, 2007). They help normalise the problems that arise within organisations as they evolve from phase to phase (Koroloff \& Briggs, 1996).

For theorists, it is no less important to re-evaluate established models and validate against recent conceptual thinking and empirical research to ensure academic insight remains robust and impactful. This paper responds to a call for conceptual papers (MacInnis, 2011) agreeing that, through the process of discovery, the quality of our ideas can be improved (Zaltman, 1983) and areas for future empirical research identified (Yadav, 2010). It adopts the definition of conceptualisation as a 'process of abstract thinking involving the mental representation of an idea' (MacInnis, 2011, p140).

The purpose of this paper is to review and critically re-examine the concept of life-cycle. In particular, the paper challenges the contemporary relevance of the construct upon which life-cycle theory is anchored. Through adopting an 'expert's mind' (R. Li, 1996), based on what is seen, known and observable, it revisits the prevailing view and identifies why revision is necessary. Through combining this with a 'beginner's mind' (R. Li, 1996), based on seeing things as if for the first time, it re- 
conceptualises life-cycle theory and identifies novel insights through a specific sector exemplar. It agrees that 'revision is more strongly related to the context of justification because it takes what is known or presumed to be and sees it differently' (MacInnis, 2011, p144). In this way, it presents one of the four identified routes for conceptual papers, that of envisioning new ideas through revising an existing concept (MacInnis, 2011).

The paper extends the human metaphor of life-cycle through identifying three generations of theory development. The first is anchored on the original PLC and the second is the extension into brand and organisational life-cycles. This paper then discusses the need to revisit the constructs underpinning lifecycle theory within a contemporary context. Over the last fifty years, there have been significant developments in marketing practice including global competition and internet-based search and purchase. However, life-cycle theory has not evolved to reflect these changes, particularly the development of more dynamic relationships between brands and consumers. Non-profit presents a rich seam to explore these issues having seen an exponential growth in the number of new non-profit organisations (NPOs), innovative use of new media to reach wider audiences with scarce resources, and increasing responsibility within society to support the most vulnerable. The sector is economically important in size, growth and population reach. Within the UK alone, there are 166,000 voluntary organisations with a combined income of $£ 47.8$ billion. The sector contributed $£ 15.3$ billion to GDP and employed over 800,000 people (NCVO, 2018). Over a fifth of adults volunteer formally at least once a month (Cabinet-Office, 2017). Behind these figures are a wide range of organisations including social enterprises, housing associations, sports clubs, universities, trade associations, socially-minded crowdfunded initiatives and public advocacy groups. This paper recognises 'general charities' (NCVO, 2018) as by far the largest component of the non-profit sector (Cabinet-Office, 2017) and therefore 
focuses on this organisational type. However, the implications of the alternative framework presented extend to the broader non-profit context.

The non-profit sector is also theoretically underexplored, particularly with respect to brand and stakeholder relationships (Andreasen, 2012; Venable, Rose, Bush, \& Gilbert, 2005). Life-cycle has the potential to unlock the dynamic nature of NPOs through mapping changing characteristics. It offers a theoretical framework through which to understand a diverse organisational landscape, dominated by mission, values and emotion. Re-examining the contemporary relevance of one of the core marketing theories within a specific context, where it has significant potential to contribute to our theoretical understanding of that sector, is attractive. Therefore, non-profit offers a powerful exemplar with which to examine the contemporary relevance of PLC.

Building upon a review of the first and second generations of life-cycle theory, the paper discusses the underpinning organisation-centric constructs of strategic and market orientation (Baumgarth, Merrilees, \& Urde, 2013; Gebhardt, Carpenter, \& Sherry Jr, 2006). It identifies that as organisations have become more responsive to customer needs, customers themselves have also demonstrated a desire for greater engagement, which has been well documented in recent research (Chiang, Wei, Parker, \& Davey, 2017; Dessart, Veloutsou, \& Morgan-Thomas, 2016; Hollebeek, Conduit, \& Brodie, 2016; Leckie, Nyadzayo, \& Johnson, 2016; Maslowska, Malthouse, \& Collinger, 2016). The paper introduces the social exchange construct as relevant for understanding the desire by customers to engage with organisations. The paper presents a revised theoretical framework; a third generation of theory development, through which to understand life-cycle theory, based on the engagement between stakeholder and non-profit organisation. It concludes with a roadmap for future empirical research in order to extend and validate that reconceptualisation (Yadav, 2014). The methodology is narrative literature review (Gephart, 2004) supported by secondary research from specialist practitioner reports. 


\section{Early Adoption of Product Life-Cycle Theory}

The original PLC is widely accredited to the economist Vernon (1966). However, PLC was being discussed decades earlier with five stages of product life being described as creation, adaption, popularisation, large scale production and abandonment (Cherington, 1924). Debate accelerated in the 1950s and 1960s as PLC became a popular subject for dissertations (Beville, 1966; Rothman, 1967;

Stobaugh, 1968), as well as a focus for academic advice to managers (Clifford Jr, 1965; Levitt, 1965;

McFall, 1969; Scheuing, 1969). Nevertheless, empirical validation remained elusive (Cox Jr, 1967; Polli

\& Cook, 1969) and use of it as a predictive tool was not widespread (Kotler, 1968). The traditional visualisation of PLC is shown in Figure 1. 
Figure 1: Product Life-Cycle Model

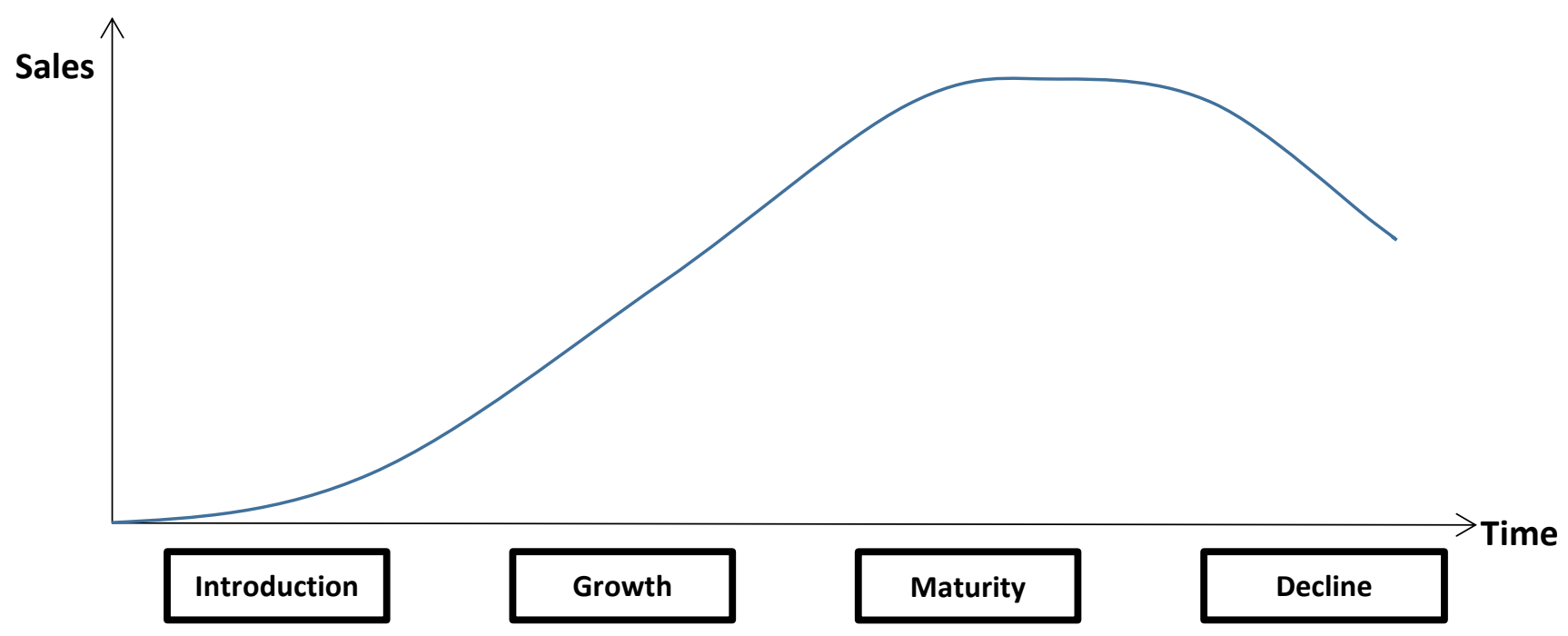


As the economic backdrop moved from an age of growing prosperity and rising consumer expectations to one of inflation and slower growth, dissenting voices could be heard as to the wisdom of PLC driven product proliferation. In particular, the structure of PLC, including assumptions of linear progression from one stage to another, clear delineation of stages, and the inevitability of a product passing through all four stages, was challenged (Dhalla \& Yuspeh, 1976; Field, 1971). Critics have pointed to the lack of empirical 'proof' underpinning the models and the complexities of the many different versions (Clancy \& Krieg, 2004; Moon, 2005). However, at the heart of the debate on PLC relevance is the issue of the cause and effect; whether the PLC is the dependent variable of the marketing actions of the organisation or whether the organisation takes action in the light of the stage of PLC they understand themselves to reside within (Dhalla \& Yuspeh, 1976). The risk with the latter is that the stage of PLC becomes a selffulfilling prophesy, with organisations acting in a way that is consistent with their perceived PLC stage, which in turn strengthens the likelihood of them residing within that stage (Clancy \& Krieg, 2004).

Despite this, PLC has become a widely researched and established theoretical framework. As Levitt (1965) believed:

One of the greatest values of the life cycle concept is for managers about to launch a new product. The first step for them is to try and foresee the profile of the proposed product's cycle ... Time spent in attempting this kind of foresight not only helps assure that a more rational approach is brought to product planning ... it can create valuable lead time for important strategic and tactical moves after the product is brought to market (Levitt, 1965, p84). Therefore, one implicit assumption underpinning PLC that can be observed is that progress is organisation-driven rather than customer-led; it is managed by the company and planned as part of business strategy (Anderson \& Zeithaml, 1984; Levitt, 1965). It assumes the rational behavior of the 
firm (Cyert \& March, 1963) where creation of utility for the customer brings economic reward (Hicks, 1956). Essentially, demand is created.

The second assumption underpinning PLC is that products are dynamic, that their characteristics change over time, commonly measured by contextual factors, such as growth, time, and revenue. The implication for managerial practice is that through understanding the stages of a product's life cycle, better decision making can be made about elements of the marketing plan such as price, product extensions, and place as the product moves through different phases of life. For example, an exclusive distribution strategy and premium price positioning during growth phases may both be 'relaxed' to drive demand during maturity and decline phases. Accurate prediction of the points of transition from one stage to another enables the company to plan ahead, to act rather than having to react. It is through the observation of these two underlying assumptions upon which the theory is anchored that PLC can be evaluated and contemporary relevance assessed.

\section{Second Generation Life-Cycle Theory}

PLC subsequently morphed into a second generation of marketing literature with two distinct strands: organisational life-cycle (OLC) (Danny Miller \& Friesen, 1983; Mintzberg, 1984; Pledger, 1981) and brand life-cycle (BLC) (Brexendorf, Bayus, \& Keller, 2015; Eisend \& Stokburger-Sauer, 2013). Effectively, this second generation of theory moves 'up a tier', no-longer simply considering the life of an individual product but instead, focusing on understanding the wider organisation or brand within which multiple products and services may reside.

There is a myriad of versions of the OLC, ten of which were reviewed by Cameron and Whetton (1981) who subsequently identified four common stages, as shown in Table 1. 
$\underline{\text { Table 1: Milestones in Organisational Life-Cycle Development }}$

\begin{tabular}{|l|l|l|}
\hline Key Authors & Stages & Stage Description \\
\hline Cameron \& Whetten (1981) & 4 & Entrepreneurial, Collectivity, Formalisation \& Control, Elaboration of Structure \\
\hline Hasenfeld \& Schmid (1989) & 6 & As above plus Decline and Death \\
\hline Bailey \& Grochau (1993) & $3+3$ & Entrepreneurial, Team-building, Bureaucracy plus Stagnation, Renewal or Death \\
\hline
\end{tabular}


Of particular interest is the work of Bailey and Grochau (1993) who argued that during the final stage the organisation can move in one of three directions: stagnation, death, or renewal. They also identify critical transitional points that either progress the organisation to the next stage of development or, if not recognised, may lead to stagnation or reversal to a previous developmental stage. These transitional points are particularly observed at moments of organisational crisis. Each phase of the OLC is characterised by contextual dimensions, such as age and growth, but also structural dimensions, such as capability and purpose. The early entrepreneurial stages are defined by flexibility, simplicity, and informality whereas mature organisations have been described as inflexible, complex, and formal (Engelen, Brettel, \& Heinemanr, 2010). In particular, the stage of OLC has been shown to be a stronger predictor of market orientation than the age or size of the organisation (Engelen et al., 2010; Wong \& Ellis, 2007). Consistent with the first generation of life-cycle theory, the organisation is the analytical lens through which change is observed.

In addition to OLC, life-cycle theory has also been developed from the brand standpoint. Within literature, there is debate as to the role of brand. One perspective argues for a choice of brand positioning at the start of brand life based on perceived consumer need, whether functional, symbolic or experiential (Park, Jaworski, \& Maclnnis, 1986). The subsequent introduction and management is true to that initial positioning. The role of the brand does not change between phases. A more popular view argues that the role of brand does change over time, for example over six stages, such as from unbranded to brand as reference, personality, icon, company, and policy (Goodyear, 1993). It does not follow that a brand will move through all six stages; they can enter at different points and may not migrate to the full ‘brand as policy’ endpoint.

Within the academic discussion of brand as life-stage is a recognition of the organisation-centric focus of extant theory, of 'push' brand strategy rather than considering the contemporary customer 
perspective, where individuals experience brands through a variety of touchpoints over their lifetime, not all of which are organisation controlled, and through the lens of their self and social identity. Although not framed in dynamic life-stage terms, De Chernatony and Riley (1998) identified twelve definitions of brand. They observe that six (including brand as legal instrument and brand identity) are organisation driven. With the remaining six (including brand as image, values, and personality) the focus moves from an organisation communicating to customers to customer perception of the brand. This idea builds on the work of Fournier (1998) who argues the relationships between customer and brand are a 'process phenomena: they evolve and change over a series of interactions and in response to fluctuations in the contextual environment' (Fournier, 1998, p344). As the relationship deepens, so does the importance of the customer's value system, the relationship with the brand, and the potential for the brand to add value to the customer (McEnally \& De Chernatony, 1999). This shift in the underlying theoretical construct from organisation to customer is important for the contemporary context. It presents an opportunity to reconsider the construct upon which life-cycle theory rests, particularly within the non-profit context where traditionally the organisation is the brand. The implication is not only that the distinction between BLC and OLC appears artificial, or purely linguistic, rather than being theoretically distinct. More fundamentally, it is the engagement between the customer and the organisation that can define which life-stage the organisation rests within rather than being a purely one-directional organisation construct.

\section{Life-Cycle within the Non-Profit Context}

Although life-cycle theory has not been widely applied to the non-profit context, there have been pockets of insight, for example, mapping the attributes of the incubator phase of NPOs (Bess, 1998) and describing structural changes amongst human service non-profits (Bailey \& Grochau, 1993; Hasenfeld \& Schmid, 1989). Zerounian, Shing, and Hanni (2011) examined network organisations and identified 
four phases of development: Sharing phase (formation), Learning phase (focus and growth), Action phase (productivity and sustainability) and, finally, the Decline/renewal phase.

Consistent with OLC, Tapp, Lindsay, and Sorrell (1999) also underpin their non-profit life-cycle framework with the organisational strategic orientation construct. They argue that NPOs adapt as they move through different phases of strategic orientation which they label Cause, Funding, and Need. The Cause is often to help solve a particular problem whether large scale, such as the reaction to disasters like the Asian tsunami, or small scale, such as local fundraising to support a sick child. Once the funds are raised, the role of the charity ends or migrates into a broader mission. The primary role for brand during this Cause phase is to build awareness of the problem (not the solution) and establishing credibility for the charity. The researchers identify that some charities never move beyond this first phase, preserving a simple structure and focused internal capability (Tapp et al., 1999).

The second phase identified is a strategic orientation of the organisation to secure Funding. In an increasingly competitive environment, the role of the brand is distinct from the Cause phase and concerns building differentiation to effectively target donors. Organisational effort focuses on relationship building and making it easy to give. Communications can feature the 'victim' or negative imagery to stimulate an empathetic consumer response. The objective is to achieve standout and convert that differentiation into funds donated, particularly in situations of intense competition or waning public interest.

The final phase within their model describes a Need orientation. The mission of the charity is focused on meeting the needs of the service users in a particular way. As charities move into this phase, a visible sign is often a re-branding exercise, away from negative labelling towards a more positive and proactive positioning (Lee, 2013), such as The Spastics Society to Scope and Help the Aged/Age Concern to Age 
UK. Both the functional and symbolic roles of the brand contribute to building a distinct positioning. It attracts supporters, including donors and volunteers, who share the vision. For this stage of organisational development in particular the brand is a valuable asset (Tapp et al., 1999).

The generalisability and subsequent impact of this framework is limited by the number of exceptions that do not fit the model. Some charity brands are synonymous with a particular cause, often a specific health issue, such as the Stroke association, Parkinson's UK, or the Cystic Fibrosis Trust. In these cases, the brand represents both the interests of service users, support for their families and being part of the solution going forward. As brand leader for a particular cause, they also become the automatic choice for people who become 'personally connected' with the cause (Hubert \& Kenning, 2008). Supporters come to the charity through the cause and work with the charity to promote awareness and raise funds from the broader community. The NPO is anchored around the Cause and does not move beyond this phase. Secondly, the maturity of the charity market results in many of the top 100 charity brands occupying the final Need phase of the life-cycle. There are examples of successful new charities, such as Help for Heroes, but they are rare. In addition, high profile charities, such as Comic Relief or BBC Children in Need, exist purely to raise funds; they inhabit the second Funding category without starting in Cause or planning to migrate to Need. They achieve impact through services provided by other charitable organisations. Despite enthusiastic public engagement during their annual media moments, these non-profits focus on intense bursts of involvement rather than deeper continuous engagement.

Therefore, as the 'Cause, Funding, Need' framework is built upon the strategic orientation construct (Lester, 2004; Storey \& Hughes, 2013), each phase represents a different priority of activity within the organisation. The Cause and Need orientations both concern mission and subsequent communication; how the organisation understands its purpose in life, whether that is specific problem solving or broader solution provision. However, the Funding orientation reflects capability building, not mission. Even 
within this funding phase, communication of mission will need to reflect a cause or need. Also, the requirement to raise funds exists throughout the life of a NPO to pay for achievement of that mission. It can be argued that the need for funding is most vital in the early stage of the organisation to ensure critical mass and survival. Finally, the model only harnesses part of strategic orientation theory. It does not discuss the market orientation (MO) of the organisation, a construct at the heart of studies of strategic orientation, and one built upon external stakeholder focus (Gatignon \& Xuereb, 1997; Liao, Foreman, \& Sargeant, 2001; Storey \& Hughes, 2013).

There have been no recent applications of BLC theory to the non-profit context. There is, however, research that recognises the dynamic nature of charity brands. Consistent with other sectors, NPOs must adapt to changes in economic conditions, such as intensifying competition both for stakeholders, such as service beneficiaries, advocates and volunteers, as well as funding. A visible indicator of dynamic change within NPOs is corporate rebranding (Merrilees \& Miller, 2008), a phenomenon that goes beyond product re-branding due the complex nature of stakeholder relationships with the organisation as well as implications for culture, identity, and image (Lee, 2013). The change in external visual identity is easily observed but the rebranding is often also the indicator of significant change within the organisation (Hankinson, Lomax, \& Hand, 2007). This can be interpreted as a moment of transition from one phase of organisational life to another. The process of corporate rebranding has been described as three phased. Stimulated by a trigger, phase one sees brand understanding built through market and stakeholder research leading to a revised vision for the brand. During phase two, internal buy-in to the new brand vision is built as well as the external re-branding exercise and strategy implementation. In phase three, the focus is stakeholder buy in and integrated marketing campaigns (Dale Miller, Merrilees, \& Yakimova, 2014). Within the non-profit context in particular, three tensions have been identified as present during the corporate rebranding process: realignment of external image with internal identity, 
engaging multiple stakeholders, and balancing marketing requirement with organisational identity (Lee, 2013).

Therefore, it can be argued that the limited literature that examines life-cycle theory within the nonprofit context have exhibited a weak connection to theory, limited generalisability, and lack of recent revision in the light of significant changes within the marketing landscape. In contrast, there is robust evidence of the dynamic nature of NPO brands but a lack of frameworks, anchored in theory, to describe and understand that transition.

What makes this void particularly interesting is the stark contrast with the significant developments in marketing thinking of related constructs, including MO and the nature of customer engagement. Jaworksi and Kohli (1993) define MO as:

organisation-wide generation of market intelligence pertaining to customers, competitors and forces affecting them, internal dissemination of the intelligence and reactive as well as proactive responsiveness to the intelligence (Jaworski \& Kohli, 1993, p131).

Likewise, Engelen et al. (2010), identify that life-stage is a moderator between MO and performance, particularly considering organisational structure. Both studies clearly view MO as an organisationcentric construct. This is either a cultural perspective, the mindset of the company (Narver \& Slater, 1990), or behavioral including attempting to meet customer needs through marketing activities, such as segmentation, customisation, and relationship management (Kohli \& Jaworski, 1990). However Urde, Baumgarth, and Merrilees (2013) shift the construct closer to the customer through defining it as an 'outside-in approach', anchored in brand image and satisfying the needs and wants of the customer and other stakeholders. This is in contrast to their definition of brand orientation, which is described as 'inside-out', meeting customer needs but within the parameters of brand identity (Urde et al., 2013). 
Over a similar time-frame, debates about the organisation management of the customer relationship (Kumar, 2010) have shifted to discussions of the customer engagement ecosystems (Maslowska et al., 2016), co-constructing brand culture (Schembri \& Latimer, 2016), user generated content (Malthouse, Calder, Kim, \& Vandenbosch, 2016), and developing deeper understanding of the drivers of customer engagement (Chiang et al., 2017; Dessart et al., 2016; Hollebeek et al., 2016). Therefore, the academic thinking behind the construct of MO has evolved beyond the organisation-centric perspective of traditional life-cycle theory to an engagement relationship between the customer and the organisation that is more democratic in power and dynamic in nature. However, these constructs now need examining within the specific context of non-profit to assess relevance and fit.

\section{Developing a Third Generation of Life-Cycle Theory for the Non-Profit Context}

\section{Market Orientation Construct}

As a theoretical construct, $\mathrm{MO}$ is anchored in customer focus; where an organisation bases decisionmaking on current and future customer needs (Gebhardt et al., 2006; Jaworski \& Kohli, 1993; Kohli \& Jaworski, 1990). It is not simply the generation of market intelligence that identifies it as market orientated but also the dissemination of, and responsiveness to, that insight. Narver and Slater (1990) operationalise MO as an organisational culture that creates superior value for customers through customer orientation, competitor orientation and inter-functional coordination. The customer is at the heart of both definitions.

MO delivers mission-based goals as it has been shown to drive financial performance in commercial sectors (Baker \& Sinkula, 1999; Liao et al., 2001; Slater \& Narver, 1994). However, for NPOs, it is driven indirectly through three dimensions: stakeholder satisfaction (where stakeholders are defined as beneficiaries and other external supporter groups such as donors, volunteers and advocates, both current 
and potential), peer reputation, and resource attraction (Shoham, Ruvio, Vigoda-Gadot, \& Schwabsky, 2006). A MO culture not only predicted a growth in resources and higher levels of customer satisfaction within the non-profit context but also a strengthening of reputation amongst peers (Gainer \& Padanyi, 2002). However, there is also evidence of mission drift away from community building and advocacy towards service provision (Maier, Meyer, \& Steinbereithner, 2016), so the relationship between MO and achievement of mission-based goals needs further exploration.

Perhaps it is for this reason that, despite the widespread observation of increasing MO of NPOs (Macedo \& Carlos Pinho, 2006; Sargeant, 2009; Shoham et al., 2006), there remains unease within the sector. Language around brand remains anchored in values (Sanders, 2015; Stride, 2006) and intraorganisational collaboration (Kylander \& Stone, 2012). Sargeant (2009), in particular, has expressed concern over the application of concepts developed in the for-profit sector, such as market orientation, to the non-profit sector, recommending societal orientation as a more suitable alternative (Liao et al., 2001). The dominant observed relationship is between the brand and donor stakeholder group (Bennett, 1998; Michel \& Rieunier, 2012; Venable et al., 2005). Strengthening the gathering and dissemination of market intelligence about donors has a clear and measurable impact (Balabanis, Stables, \& Phillips, 1997; Bennett, 1998). It also concerns NPO behavior, that is what they do, rather than mission, which speaks to who they are (McDonald, 2007; Sanders, 2015). It is less threatening, in contrast to debate about NPO brand as a competitive lever. However, this is changing in the face of increasing pressure on resource acquisition and lack of differentiation within a cluttered operating environment (Dato-on, Keller, \& Shaw, 2015).

MO resides within the broader environment of increasing professionalism within society (Hwang \& Powell, 2009). NPOs are no exception (Carlos Pinho, Paula Rodrigues, \& Dibb, 2014; Maier et al., 2016; Urde et al., 2013). The transition from amateur to paid professional, from volunteer founder to 
executive leadership is well underway as NPOs become major service providers (Chad, 2014). The resultant changes in structure can include:

the use of managerial and organisation design tools developed in for-profit business settings, and broadly framed business thinking to structure and organise activity (Dart, 2004, p294).

The impact on ways of working within NPOs has been identified in four distinct dimensions: programme goals, organisation of service delivery, organisation management, and organisation rhetoric (Dart, 2004). From a resource perspective, professionalisation can strengthen the ability of the NPO to attract and retain qualified staff (Guo, 2006). Enhanced and formalised support structures may drive overall volunteer participation, although they may also potentially alienate grassroots activists. (Maier et al., 2016). Increased fundraising capability through importing strength and depth has a direct and positive impact on net income for the NPO (Betzler \& Gmür, 2016). However, the impact on culture and identity of the NPO is not only due to the incoming expertise but also the 'integration of professional ideals into the everyday world of charitable work' (Hwang \& Powell, 2009, p268).

The translation of the MO construct from the commercial to the non-profit context must consider two situational differences - the complexity of stakeholder relationships and the mission delivery goals, rather than financial goals, of the organisation. In the absence of existing terminology, three distinct customer relationships are identified and labelled in Figure 2. 
Figure 2: Market Orientation Relationships
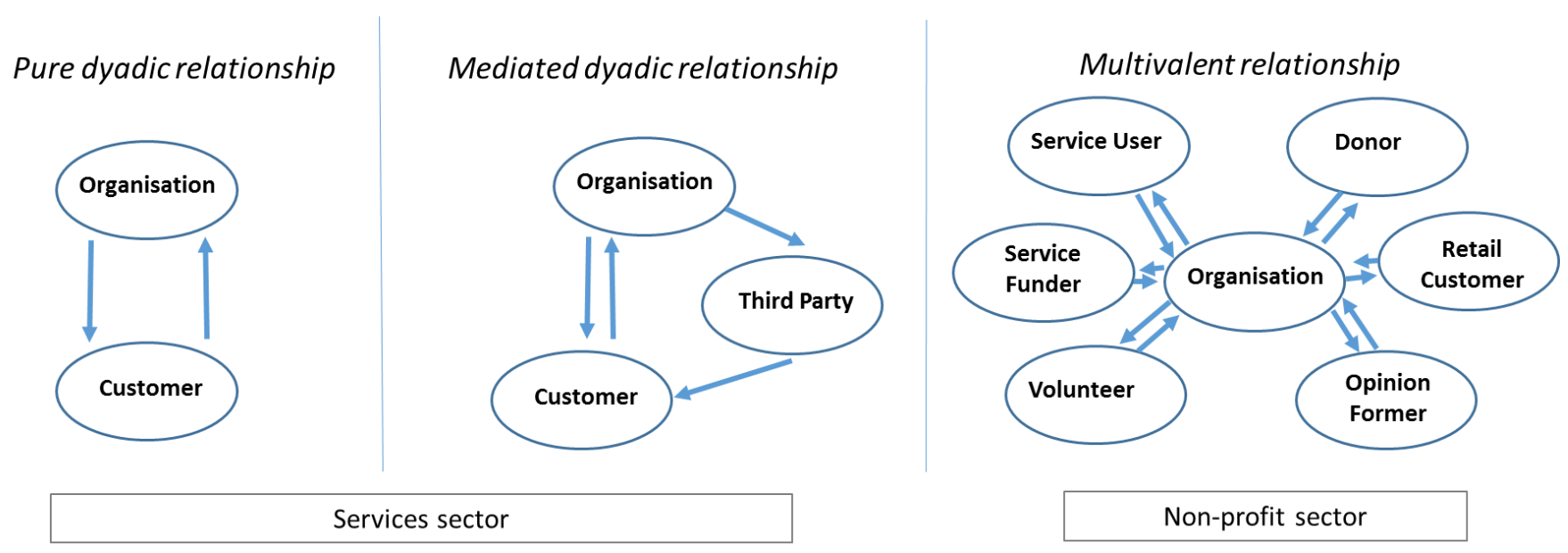
Service companies may demonstrate pure 'dyadic' customer relationships or 'mediated dyadic', through a third party, such as a booking agent. However,

identifying who an organisation's customers are is even more complex when service is provided to one party, but payments are received from another (Kohli \& Jaworski, 1990, p4).

NPOs have multiple customers, including service beneficiaries, retail customers, volunteers, individual donors, service funders and opinion formers. This moves beyond dyadic to what can be described as 'multivalent' stakeholder relationships.

Each stakeholder group can be defined as customers, particularly given the importance of social exchange theory (Bagozzi, 1975; Emerson, 1976; Venable et al., 2005) and symbolic consumption theory (Khodakarami, Petersen, \& Venkatesan, 2015; Randle \& Dolnicar, 2011; Wymer Jr \& Samu, 2002) observed within the non-profit sector. The level of MO will not be uniform across these relationships (Padanyi \& Gainer, 2004); in effect the NPO needs to manage each of these 'multivalent' relationships, all with a distinct impact on performance and culture, through understanding and fulfilling the exchange that stakeholders require.

\section{Social Exchange Construct}

An important theoretical construct within the non-profit context is social exchange (Blau, 1964;

Emerson, 1976). It argues the 'voluntary actions of individuals are motivated by the rewards they are expected to bring' (Blau, 1964, p91). Social exchange theory assumes people act in their own selfinterest. The motivation underpinning the exchange 'lies in the social and psychological significance of the experience, feelings and meanings of the parties in the exchange' (Bagozzi, 1975, p36). However, in this context it goes beyond marketplace commodity exchange, considering instead the donation of personal time and money and rationally expecting benefits, such as meeting personal goals and needs, in 
return. Venable et al. (2005) argue that although there may be social benefits from buying commercial brands, such as status and security, they are more salient amongst non-profit brands.

Because of the intangible, service-orientated nature of non-profit organisations, we posit that social exchange and trust play an important role in consumer's decisions of whether to donate money, time, or in-kind goods and services to such organisations (Venable et al., 2005, p296).

Stakeholders consider the rewards of action at an abstract level - including personal satisfaction, social approval or humanitarianism. The prospective benefits of achieving those personally important goals are weighed against the cost of volunteering, donating or becoming an advocate for the NPO. For volunteers in particular, it identifies that time is not the only cost involved; other costs include the opportunity cost of not participating in other activities, potential stigma through association with socially difficult causes (Omoto \& Snyder, 1995), plus the emotional cost of supporting someone potentially vulnerable. There has been a clear and robust articulation of the functional goals people are seeking to meet through volunteering - including social, career, and learning (Bénabou \& Tirole, 2003; Mowen \& Sujan, 2005).

Blau (1964) believed the social exchange was contingent on the rewarding nature of other people's reaction; if there was no reaction by others, the action would not have taken place:

The tendency to help others is frequently motivated by the expectation that doing so will bring social rewards, the social approval of those whose opinions we value is of great significance to us (Blau, 1964, p17).

Indeed, a major national study of civic participation identified:

that if there is not some mutual benefit then people's involvement may falter... Interviewees often spoke about gaining from participating (in terms of friendship, satisfaction, influence, support, 
confidence, skills and recognition) as much as they gave (in terms of time, money, compassion, care and energy) (E. Brodie et al., 2011, p5).

The social exchange construct involves an evaluation of perceived costs and benefits of involvement by stakeholders in NPOs. As the exchange is salient and explicit, it can be recalled by volunteers, which might explain its prominence in both national volunteering surveys (Cabinet-Office, 2017) and academic studies (Clary et al., 1998).

Alternative theoretical perspectives to exchange have been proposed, including gift giving, altruism and sharing (Belk, 2009; J. A. Piliavin \& Hong-Wen, 1990; Vaughan, 1997), despite the distinctions between these theories being imprecise (Belk, 2009). However, social exchange, in contrast to commodity exchange, is closer in theory to 'the gift paradigm (that) emphasises the importance of giving to satisfy needs. It is need-orientated rather than profit orientated' (Vaughan, 1997, p14). It is the giving of time and money in return for needs met that creates the relationship between stakeholder and NPO. As Vaughan (1997) argues, in making or receiving the gift, the existence of the other party is recognised. Indeed, Benkler (2004) described gift theory as concerned with the 'production and reproduction of social relations through the exchange' (Benkler, 2004, p4). Even Giesler's (2006) study of gift giving in the context of Napster discusses the social relationships gained as a result of music sharing and high social status earned through being a super-sharer. Going further, the concept of whether the perfect gift exists has been challenged; gifts are observed to come with an expectation of reciprocity at another time (Giesler, 2006), caught up in mutual obligation (Mauss, 1967). In effect they become a practical form of exchange (Belk, 2009).

Altruism has been defined as a 'general disposition to selflessly seek to help others' (Mowen \& Sujan, 2005, p173), and has been particularly found in the cases of blood or organ donation (Titmuss, 1971) 
and bystander heroism (I. M. Piliavin, Rodin, \& Piliavin, 1969). However, Wilson and Musick (1997) argue our broader understanding of altruism underestimates the role of self-identity, for example, someone who thinks of themselves as the type of person who helps others even if they are not recognised for it. Several, more recent psychological studies have demonstrated that social identity is an important determinant of prosocial behavior (Blader \& Tyler, 2009; Tidwell, 2005). In effect, meeting these needs is what is received in return for the prosocial action, undermining the concept of nonreciprocal altruism.

In contrast, sharing has been described as non-reciprocal prosocial behaviour (Benkler, 2004), a communal act that links us to other people (Belk, 2009). It has been particularly observed within the concept of the extended self, often the immediate family, and concerning mutuality of possession rather than transfer of ownership. When the context under exploration concerns organisations and their relationship with their stakeholders, as with this paper, it is the concept of 'sharing out' rather than 'sharing in' (with the extended self, often family) that is more relevant. 'Sharing out' is seen as closer to gift giving and commodity exchange (Belk, 2009), and therefore social exchange can be viewed as closer still. In addition, 'sharing in outside of the immediate family' has been found to be relatively uncommon (Belk \& Llamas, 2012). Therefore, social exchange is identified as the most appropriate theoretical frame through which to explore the non-profit organizational context, consistent with other research in this field (Mathur, 1996; Randle \& Dolnicar, 2011; Venable et al., 2005; Wymer Jr \& Samu, 2002).

When a NPO understands this social exchange, they are in effect considering the needs of their stakeholders, both current and potential. They understand that in order to sustain the multiple stakeholder relationships needed to deliver their mission, as an organisation they must fulfil their side of the exchange. Long term stakeholder relationships will not be established if the stakeholders are purely 
viewed as a source of resource, whether funding or manpower. The NPO must understand what each stakeholder group requires in return. In theoretical terms, they need to be market orientated.

\section{A New Model of Stakeholder Engagement}

Therefore, it is the level engagement between the NPO and its stakeholders that now presents a true reflection of its phase of organisational development. Moderating that relationship is the level of MO of the organisation, particularly towards customers/stakeholders, and the level of social exchange that those customers/stakeholders desire from the organisation in return for time, money and goods offered. The theoretical model describing these relationships is presented in Figure 3. 
Figure 3: Theoretical Model of NPO-Stakeholder Relationships




In situations where the organisation is highly market orientated and understands the need for focus on the external stakeholder, and those stakeholders have a strong desire for social exchange, where personal needs are met through donation of time, goods or money, then there will be a high level of engagement between the two. In situations where the stakeholders have low involvement with the NPO and/or the NPO is inwardly focused, lacking ambition to build multivalent relationships then the level of stakeholder engagement will be low.

The level of MO that the NPO exhibits is, in turn, influenced by three factors: the strength of organisational ambition, the competitive context, and the internal capabilities within the organisation. Not all NPOs need or desire stakeholder engagement. Some are funded purely by central government grants, reducing the need for the charity to engage with individual donors, product/service customers, volunteers or fundraisers: the need for social exchange is not only less but also focused on fewer stakeholders. Others exist to fulfil a specific and time-bound mission, such as fundraising for an event; once achieved, the NPO will cease to exist. However, for the majority of NPOs, the level of MO is determined by the level of strategic ambition within the organisation and how far they want the organisation to progress in delivering its mission. This will also, in part, depend on the competitive context. The more competitive the specific cause category or broader civic participation environment, the greater the need to be differentiated and stakeholder focused. The ability to deliver that opportunity will, therefore, also be determined by the capabilities within the organisation. The skills and expertise needed at each phase will evolve. The challenge is whether the NPO recognises that requirement and can harness the opportunity through actively ensuring those required capabilities are in place.

In turn, the level and form of social exchange required by the stakeholders depends on their sense of self, congruence with the values of the organisation, and reaction of friends and family. The concept of self is important to the stakeholder; it affects the choices they make, directing behavior towards 
enhancing self-concept through the consumption of goods as symbols. In this way, people gain or reinforce their sense of self through the services or goods they buy and what it says about them. The construct of self has been divided into five categories - ideal self, actual self, social self, ideal social self, and self-expectations (Sirgy, 1982). Actual self is how a person sees themselves in reality whereas ideal self is how the person would like to perceive themselves in an ideal world. Social self is how we present ourselves to other people (Champniss, Wilson, \& Macdonald, 2015). Research by Achouri and Bouslama (2010) demonstrated that people look for opportunities that enhance their identities and, when they find them, that relevant identity is reinforced. The more salient self-concepts have been identified as being the ones that are more likely to affect behavior than those that are not so important (Arnett, German, \& Hunt, 2003). The implication is that the stronger the congruity between the stakeholder's actual or ideal self and those of the product or service brand, the stronger the preference for that brand (Brunsø, Scholderer, \& Grunert, 2004; Malhotra, 1988). Finally, choice of, and the level of engagement with, a specific NPO is made within a wider psycho-social context; one where the opinions of family, peers and community play a role. This is well described within the expressive and emblematic constructs of symbolic consumption theory (Hoyer, MacInnis, \& Pieters, 2012) where people choose to associate themselves with a brand in part due to what it says about themselves to other people or to associate themselves with a particular group, such as a faith community or local residents. Potter (2011) agrees this behavior is often anchored in status-seeking rather than simply the pursuit of authentic activities and groups.

\section{Re-envisaging Life-Cycle Theory for the Contemporary Non-Profit Context}

Therefore, life-cycle theory can be evolved and re-imagined to understand and explain different stages of contemporary stakeholder engagement, underpinned by the constructs of social exchange and market orientation. In doing so, this new perspective brings a popular marketing theory in line with the 
contemporary context of both practice and theory. Explored within the non-profit context, this new engagement life-cycle is depicted in Figure 4 and defined below. 
Figure 4: Engagement Life-Cycle

Incubation $\longrightarrow$ Interaction $\longrightarrow$ Involvement $\longrightarrow$ Immersion $\longrightarrow$ Incapacitation


Incubation: At the initial 'Incubation' stage, there is little or no stakeholder engagement (Bess, 1998). The NPO exists independently of external involvement. This can be because the organisation does not need that engagement to exist, for example, the Sigrid Rausing Trust, which grants $£ 25$ million each year to support human rights but identifies recipients through internal research not applications. It can also be because the NPO is new and the engagement process is not established for reasons of context, such as age of the charity, and/or capability including lack of digital marketing skills (Amar \& Evans, 2017). This stage is labelled 'Incubation' as it represents the initial phase of organisational growth.

Interaction: The subsequent phase is one where social exchange exists with multiple stakeholder groups but it is time-bound and transaction based: their investment is not significant in terms of time or money. The value they receive in return is consistent with this investment, not life changing but enough to balance the donation of time, goods or money. This second period is labelled the 'Interaction' phase, where customers are seen as a resource to achieve the NPO mission. They are a source of funding, volunteer time and retail sales (Macedo \& Carlos Pinho, 2006). The focus of the organisation for that relationship is as a means to an end: generating enough funds or encouraging enough people to help to deliver their mission. The NPO does need to understand who and how to target to elicit that support. At a micro level, this includes young people volunteering as part of the Duke of Edinburgh award or raising money to take part in a World Challenge expedition as well as community fundraising events by local Parent Teacher Associations for school equipment. It may be rewarding and effective but achieves specific objectives and is time bound.

Surprisingly, at a macro level, it also includes high profile organisations, such as BBC Children in Need and Comic Relief. Public engagement may be passive, such as watching a mass TV event, or active, such as participating in fundraising stunts on or leading up to the 'big day'. However, they are temporally specific, a media moment, and stakeholder relationship with the organisation tends to be at 
arms-length. Despite high awareness, efficacy and perceived credibility, their objective for customer engagement is purely fundraising.

Controversially, it can also be argued that public engagement with many armed forces charities can also be placed within this 'Interaction' phase. Despite almost universal awareness, credibility of the cause and high levels of public participation in poppy buying and, to a lesser extent attending remembrance services, the relationship for those outside the immediate forces community is transactional and emotional engagement periodic. There is minimal public engagement for 51 weeks of the year. One notable exception to this was the art installation at the Tower of London (UK) in 2014 to mark the centenary of WWI. Over 5 million people attended and the subsequent public purchase of ceramic poppies raised $£ 11$ million for forces charities. However, over time as family connections to the major world wars fade, customer engagement reverts to interaction, a credible but low engagement relationship.

Involvement: During the third phase, the relationship between stakeholder and organisation is one of active 'Involvement'. Each stakeholder perceives an ongoing value in the goods or services they buy or the volunteering time they contribute. There are often multiple points of functional engagement, for example, taking part in a sponsored sporting event and wearing a pin badge or wrist band. They might also buy greeting cards from the same organisation or donate clothes to their shop on the high street. In return for participation, they receive a 'warm glow' and sense of civic duty or are entertained or gain a sense of sporting achievement. However, the relationship, which may be repeated every year, is not an exclusive relationship and it does not form a deep connection. At this phase, a donor might make one-off donations or even regular direct debits but for relatively affordable amounts and potentially to a range of charities (Sargeant \& Lee, 2004). However, between activity bursts, the level of ongoing personal engagement is often relatively low, perhaps skimming the periodic newsletter or email. 
Many larger NPOs also reside in the Involvement phase. For example, the $\mathrm{RSPB}^{1}$ has over one million members who, for payment of a modest annual membership fee, interact with the charity in variety of ways, including attending local wildlife events and making gift catalogue purchases. Over half a million people participate in their annual Big Garden Birdwatch event and there are over 2 million visits to their network of nature reserves. Supporters are empathetic with the cause, personal investment is relatively low, and the credibility of the charity to make a difference is high.

From an organisational perspective, this stage requires insight into the multivalent stakeholder relationships. The NPO needs to understand what benefit the different supporter groups perceive they receive in exchange. It requires the internal capability to target and communicate effectively. It needs to create mechanisms for engagement, such as participation events and suitable volunteering roles. In particular, it must understand the offer that its brand and mission provides customers over and above other uses of their time and money (Wymer Jr \& Rundle-Thiele, 2016), so the NPO is differentiated, not only amongst their cause sector but also within the wider non-profit and leisure choice context. The positioning of the mission might be framed through cause or need but will be underpinned by credibility and value exchange so stakeholders believe their time and money will be well spent.

Immersion: For a NPO to move beyond this stage, into a deeper, more 'Immersive' level of engagement, a strategic shift for the organisation is necessary; a real moment of transition. Moving from involvement to immersion requires regular service delivery roles where a volunteer commits significant amounts of time to fulfil the mission of the NPO. It requires donors who not only give now but also pledge legacies for the future. It requires fundraisers who not only stand outside Sainsbury's on a wet Saturday but also go online, share content and are prepared to be very public about their involvement.

\footnotetext{
${ }^{1}$ Royal Society for the Protection of Birds
} 
The level of commitment is significantly higher, as are the emotional rewards for the stakeholders. At this stage, it is much more likely to be the primary NPO that is supported, given the time and money involved. Stakeholders may support other organisations in a small way but their time, energy, and focus are with one NPO. Crucially there is also a higher level of emotional engagement that is often marked by a deep personal relevance, such as to specific health charities like Macmillan Cancer Support or Cancer Research UK. From an organisational perspective, managing these relationships requires different skills and capabilities. Understanding and meeting the need for social exchange is fundamental to meeting expectations, strengthening commitment and reducing churn. Providing multiple opportunities for periodic and regular engagement, investing in feedback communication and consistent brand differentiation maintain the momentum.

However, it requires more than simply strong communication, volunteering, and events programmes. To exhibit a high level of stakeholder engagement, there is also involvement within the organisation. Not simply active and on-going stakeholder research to inform decision making, such as the genuine customer panels of the Alzheimer's Society and HFT ${ }^{2}$ but meaningful involvement in the decisionmaking of the NPO. Culturally, this can be described as a shift from being 'for' service beneficiaries to the organisation being run in part ' $b y$ ' service beneficiaries. This can take the form of participation at trustee level, service user employment, and beneficiary panels for research and policy development feedback. It may be organic and informal involvement, for example, Homeless Link and Clink ${ }^{3}$, or more formal structures, such as the $\mathrm{RNIB}^{4}$ or $\mathrm{Mind}^{5}$ (Smith, 2015).

\footnotetext{
${ }^{2}$ NPO supporting people with learning disabilities

${ }^{3} \mathrm{NPO}$ supporting offenders

${ }^{4}$ Royal National Institute of Blind People, supporting blind and partially sighted people

${ }^{5}$ NPO supporting people with mental health issues
} 
Approximately 75 per cent of RNIB's executive board are themselves either blind or partially

sighted people. The charity seeks to recruit as many service users as volunteers as possible. It has a workforce of about 3,000 and about seven per cent are blind or partially sighted (SCIE, 2007).

NPOs start to exhibit this level of engagement orientation in the involvement stage but for a deeper relationship that participation must be meaningful, embedded and impactful on the organisation. This is much rarer, partly because it requires the organisation to be open to embrace changes in ways of working and capabilities as a result of the stakeholder participation. It also requires a strong leadership and senior team skill set to manage the engagement orientation effectively. From a theoretical perspective, although rarely related to non-profits, this level of engagement builds on the rapidly growing body of co-creation research (R. J. Brodie, 2017; Johnson Dretsch \& Kirmani, 2014; Ross, Halliday, France, Merrilees, \& Miller, 2015) and connection between MO and non-profit innovation (Choi, 2014; McDonald, 2007).

Incapacitation: The final phase of NPO development is the end game where the engagement between current stakeholders and the organisation has literally become 'Incapacitated' (Hasenfeld \& Schmid, 1989). In an ideal world, the NPO has successfully achieved its mission and is mature enough to realise it is now obsolete for current and future stakeholders. However, three other scenarios are much more likely. The first is where stakeholder trust in the NPO is fatally undermined by a scandal that they cannot recover from, such as the case of Kids Company $(\mathrm{BBC}, 2016)^{6}$. The second is where the organisation and supporters together have failed to achieve the mission, for example the Save the $8^{\text {th }}$ campaign to

\footnotetext{
6 'Kids Company' was a London based charity that specialised in supporting deprived inner-city children. Founded in 1986 by Camilla Batmanghelidjh, by 2011 it was supporting 36,000 young people each year. However, despite high profile trustees and funders, including central government, it ran into serious financial difficulty. The charity ceased operations in 2015 with significant public fallout for the trustees and founder.
} 
preserve the eight amendment in Northern Ireland banning abortion (O'Brien, 2018). The third is where the competitive context has evolved to such an extent that the NPO is incapacitated as a stand-alone organisation, such as the Lifeline Project, which at time of collapse in 2017 employed 1,300 employees and supported 80,000 drug and alcohol users (Singh, 2017). There are two observed outcomes from this situation: the organisation either ceases to exist or needs to merge with another charity to achieve critical mass and be sustainable, such as Hearing Link merging with Hearing Dogs for Deaf People in 2017 (Ricketts, 2017). The combined organisation then differentiates itself from the remaining competition. This requires a level of strategic thinking anchored in creation. In both scenarios, NPOs must re-invent themselves and develop a new mission, a new purpose, with resultant new modes of delivery and supporter groups with which to engage (McDonald, 2007). The NPO does not need to pass through all the first four stages to reach this final stage; it could become unsustainable even after the first stage if it fails to raise enough funds, or after the interaction stage through failing to differentiate, or after the involvement stage after achieving its mission. However, the time it takes each organisation to progress through each stage is unique to them.

The characteristics of each stage of the engagement life-cycle are described in Table 2. Although depicted as a linear progression of stages, there is no requirement that all stages will be completed or indeed, that moving from one stage to another is aspired, with the possible exception of moving out of vulnerable incubation stage. Successful and well known contemporary NPOs reside in each of the middle three stages, interaction, involvement, and immersion, characterised by different types of MO and stakeholder engagement. 
Table 2: Characteristics of Engagement Life-Cycle Stages within the Non-Profit Context

\begin{tabular}{|c|c|c|c|c|c|c|}
\hline Characteristics & \multicolumn{2}{|l|}{ Incubation } & Interaction & Involvement & Immersion & Incapacitation \\
\hline $\begin{array}{l}\text { Level of } \\
\text { Market } \\
\text { Orientation }\end{array}$ & \multicolumn{2}{|c|}{ None } & Low & Medium-High & High & None \\
\hline Description & Newly formed & $\begin{array}{l}\text { Foundation } \\
\text { led }\end{array}$ & $\begin{array}{l}\text { Transaction } \\
\text { led }\end{array}$ & Marketing led & $\begin{array}{l}\text { Mission and } \\
\text { culture led }\end{array}$ & $\begin{array}{l}\text { Mission } \\
\text { completion. } \\
\text { Incapacitated } \\
\text { due to scandal. } \\
\text { Lack of } \\
\text { resource. }\end{array}$ \\
\hline $\begin{array}{l}\text { Level of } \\
\text { Stakeholder } \\
\text { Engagement }\end{array}$ & \multicolumn{2}{|c|}{ None } & $\begin{array}{l}\text { Multiple } \\
\text { stakeholder } \\
\text { groups. } \\
\text { Time bound } \\
\text { relationships }\end{array}$ & $\begin{array}{l}\text { Active } \\
\text { relationship } \\
\text { building. } \\
\text { Multiple } \\
\text { touchpoints of } \\
\text { functional } \\
\text { engagement }\end{array}$ & $\begin{array}{l}\text { Stakeholders, } \\
\text { especially } \\
\text { service } \\
\text { beneficiaries, } \\
\text { integrated } \\
\text { within } \\
\text { purpose \& } \\
\text { structure. } \\
\text { High level of } \\
\text { emotional \& } \\
\text { functional } \\
\text { commitment }\end{array}$ & $\begin{array}{l}\text { Declining - not } \\
\text { sustainable }\end{array}$ \\
\hline $\begin{array}{l}\text { Strategic } \\
\text { Ambition }\end{array}$ & $\begin{array}{l}\text { Ensuring } \\
\text { survival during } \\
\text { start-up phase }\end{array}$ & $\begin{array}{l}\text { Focus on } \\
\text { maximum } \\
\text { impact } \\
\text { within } \\
\text { mission } \\
\text { boundaries }\end{array}$ & $\begin{array}{l}\text { External } \\
\text { stakeholders } \\
\text { as resource } \\
\text { to achieve } \\
\text { mission }\end{array}$ & $\begin{array}{l}\text { Brand } \\
\text { differentiation. } \\
\text { Stakeholder } \\
\text { interaction. } \\
\text { Mission } \\
\text { credibility }\end{array}$ & $\begin{array}{l}\text { Mission } \\
\text { drives culture } \\
\& \text { stakeholder } \\
\text { advocacy }\end{array}$ & $\begin{array}{l}\text { Reinvention or } \\
\text { closure }\end{array}$ \\
\hline $\begin{array}{l}\text { Competitive } \\
\text { Context }\end{array}$ & Overwhelmed. & $\begin{array}{l}\text { Protected } \\
\text { due to secure } \\
\text { funding }\end{array}$ & $\begin{array}{l}\text { Intense } \\
\text { competition } \\
\text { for resources }\end{array}$ & $\begin{array}{l}\text { Intense } \\
\text { competition for } \\
\text { loyalty }\end{array}$ & $\begin{array}{l}\text { Established \& } \\
\text { differentiated } \\
\text { positioning }\end{array}$ & Evolved \\
\hline $\begin{array}{l}\text { Organisational } \\
\text { Capability }\end{array}$ & Low & Focused & Developing & $\begin{array}{l}\text { Wide-ranging. } \\
\text { Marketing led }\end{array}$ & $\begin{array}{l}\text { Innovative. } \\
\text { Confident }\end{array}$ & $\begin{array}{l}\text { Change } \\
\text { management }\end{array}$ \\
\hline
\end{tabular}




\begin{tabular}{|c|c|c|c|c|c|c|}
\hline $\begin{array}{l}\text { Practical } \\
\text { Implications } \\
\text { for progression }\end{array}$ & $\begin{array}{l}\text { Strengthen } \\
\text { fundraising } \\
\text { capability }\end{array}$ & Not required & $\begin{array}{l}\text { Strengthen } \\
\text { marketing } \\
\text { capability }\end{array}$ & $\begin{array}{l}\text { Strengthen } \\
\text { leadership } \\
\text { capability }\end{array}$ & $\begin{array}{l}\text { Strengthen } \\
\text { governance } \\
\text { capability }\end{array}$ & Not required \\
\hline $\begin{array}{l}\text { Example } \\
\text { organisations }\end{array}$ & $\begin{array}{l}\text { No Falls } \\
\text { Foundation, } \\
\text { YACCA }^{7} \text {, } \\
\text { Mind Body } \\
\text { EDS }^{8}\end{array}$ & $\begin{array}{l}\text { Sigrid } \\
\text { Rausing } \\
\text { Trust, } \\
\text { Paul Hamlyn } \\
\text { Foundation, } \\
\text { The Starr } \\
\text { Foundation }\end{array}$ & $\begin{array}{l}\text { Comic } \\
\text { Relief, } \\
\text { Duke of } \\
\text { Edinburgh } \\
\text { Award, } \\
\text { Royal British } \\
\text { Legion }\end{array}$ & $\begin{array}{l}\text { RSPB }^{9}, \\
\text { National Trust, } \\
\text { RNLI }^{10}\end{array}$ & $\begin{array}{l}\text { Homeless } \\
\text { Link, } \\
\text { Mind, } \\
\text { RNIB, } \\
\text { Macmillan } \\
\text { Cancer Relief }\end{array}$ & $\begin{array}{l}\text { Lifeline } \\
\text { Project }^{11} \text {, } \\
\text { 4Children, } \\
\text { Kid's Company }\end{array}$ \\
\hline
\end{tabular}

\footnotetext{
${ }^{7}$ Young Adult Complex Condition Alliance

${ }^{8}$ Mind Body Ehlers Danlos Syndrome

${ }^{9}$ Royal Society for the Protection of Birds

${ }^{10}$ Royal National Lifeboat Institution

${ }^{11}$ NPO supporting people with drug or alcohol issues
} 
The implications of this alternative life-cycle framework are threefold. Through actively considering which stage their organisation is currently resting within, managers are able to reflect on the current level of strategic ambition and organisational capability. If they do aspire to move to the next level of market orientation, what needs to be in place before that can be achieved? Secondly, the framework enables them to examine their multivalent stakeholder relationships in the light of the level of social exchange currently enabled by the charity. Is there balance between the internal focus and insight on donors compared to volunteers for example? Does the organisation understand what the stakeholder values about their engagement with the charity? Do they recognise how to enhance the self-identity of its stakeholders and how to be part of their social identity within a peer group? Finally, the engagement life-cycle offers managers a framework through which to consider the long-term strategic development of the NPO. Is the ambition to achieve their mission and therefore become redundant? Or is it to have such stretching goals they can never be achieved such as 'improving the quality of life for individuals around the world' by the Bill and Melinda Gates Foundation or 'end extreme poverty' by the World Bank. If the competitive context became unsustainable would they have the governance and creativity required to manage the endgame?

\section{Contribution}

The paper contributes to a conversation about popular, embedded marketing theories and their relevance today. It builds on the work of Fournier (1998) who identifies 'the critical importance of understanding brands and consumers' relationships with them to the advancement of marketing theory' (Fournier, 1998, p365). Product life-cycle theory was developed over fifty years ago and remains prevalent within marketing pedagogy. The paper identifies two directions of life-cycle theory evolution, organisational and brand, but also argues that for service organisations with one corporate brand, the distinction is artificial to managers. OLC and the dynamic nature of charity brands are explored within the non-profit 
context, a significant but under-researched sector. Extant literature that applies life-cycle to the nonprofit context is identified, critiqued and found to be lacking a contemporary and holistic theoretical explanation of NPO development.

In seeking to challenge and re-envisage historic life-cycle models, MO theory and social exchange theory are identified as particularly relevant to the non-profit context. These provide the theoretical foundations for the development of a contemporary model of stakeholder engagement (Figure 3). The paper identifies three constructs as moderators of levels of MO: strategic ambition, competitive context, and organisational capability. It also identifies three constructs as moderators of customer desire for social exchange: sense of self, peer reaction and values congruity.

The paper then develops this conceptualisation of stakeholder engagement with NPOs into an engagement life-cycle model (Figure 4), describing the five stages as incubation, interaction, involvement, immersion and incapacitation. The distinct characteristics of each phase of organic growth are summarised in Table 2. For theorists, the paper extends and evolves our understanding of the relevance of life-cycle theory to a specific contemporary context, presenting an alternative framework through which to understand the life-cycles of NPOs. In anchoring this new conceptualisation within customer engagement, it enables the life-cycle concept to be relevant amongst theoretical discussions such as co-creation, brand touch-points and brand communities. For managers, the paper identifies the importance of understanding the ambition and capability of the NPO to enable social exchange with its multivalent stakeholder groups. It discusses benefits received by stakeholders in return for time, money or goods donated, including whether they are functional or emotional, periodic or ongoing. It presents the implications for capability-building required by the organisation to maximise stakeholder engagement in order to progress to the next phase of life-cycle and to achieve the mission. Therefore, life-cycle theory continues to present a useful framework for understanding contemporary non-profit 
organisations but only if the model itself is evolved to understand the level of engagement between the organisation and its stakeholders.

\section{Limitations and Future Research}

The purpose of the paper is conceptual theory development, envisaging new ideas through revising an existing concept (MacInnis, 2011). It focuses on one specific sector, non-profit, identifying and critiquing the application of life-cycle models within this context. However, the new engagement lifecycle presented in the paper offers a framework to understand the levels of relationship and engagement between NPOs and their stakeholders. In addition, it aspires to act as a catalyst for broader based research, identifying three research streams that flow directly from the engagement life-cycle. The first is the opportunity to identify measurable characteristics for each stage of engagement, thus enabling managers to recognise in which stage their organisation is residing and theorists to identify sector specific differences and similarities. This also enables the issue of temporality to be researched including whether the pace of change between phases is accelerating over time and, in particular, whether social media accelerates those pathways. This is envisaged to include rapid growth through on-line awareness building campaigns such as the ALS Ice Bucket challenge (Woolf, 2016) or rapid demise such as the social media storm following the Kid's Company financial difficulties (BBC, 2016). The role of social media in crowdfunding has started to be explored (André, Bureau, Gautier, \& Rubel, 2017; Y.-Z. Li, He, Song, Yang, \& Zhou, 2018) but the opportunity remains to understand how social media specifically contributes to progressing organisations through life-stages such as to maturity or decline. The 'moments of transition' also presents an opportunity for further understanding including mapping which triggers that lead from one stage to another. Finally, understanding of the engagement life-cycle would be enriched from a gathering of case studies of organisations, including non-profit, that represent best- 
in-class for each stage of customer engagement. In this way, this roadmap for future research can both extend and validate the re-conceptualisation of existing theory (MacInnis, 2011; Yadav, 2010). 


\section{References}

Achouri, M. A., \& Bouslama, N. (2010). The effect of the congruence between brand personality and self-image on consumer's satisfaction and loyalty: A conceptual framework. IBIMA Business Review, 2, 34-49.

Amar, Z., \& Evans, D. (2017). Charity digital skills report. [Online] Available: https://www.skillsplatform.org/content/charity-digital-skills-report-2017 (March 23, 2017).

Anderson, C. R., \& Zeithaml, C. P. (1984). Stage of the product life cycle, business strategy, and business performance. Academy of Management Journal, 27(1), 5-24.

André, K., Bureau, S., Gautier, A., \& Rubel, O. (2017). Beyond the opposition between altruism and self-interest: Reciprocal giving in reward-based crowdfunding. Journal of Business Ethics, 146(2), 313-332.

Andreasen, A. R. (2012). Rethinking the relationship between social/nonprofit marketing and commercial marketing. Journal of Public Policy \& Marketing, 31(1), 36-41.

Arnett, D. B., German, S. D., \& Hunt, S. D. (2003). The identity salience model of relationship marketing success: The case of nonprofit marketing. Journal of Marketing, 67(2), 89-105.

Bagozzi, R. P. (1975). Marketing as exchange. Journal of Marketing, 39(4), 32-39.

Bailey, D., \& Grochau, K. E. (1993). Aligning leadership needs to the organizational stage of development: Applying management theory to nonprofit organizations. Administration in Social Work, 17(1), 23-45.

Baker, W. E., \& Sinkula, J. M. (1999). The synergistic effect of market orientation and learning orientation on organizational performance. Journal of the Academy of Marketing Science, 27(4), 411-427. 
Balabanis, G., Stables, R. E., \& Phillips, H. C. (1997). Market orientation in the top 200 British charity organizations and its impact on their performance. European Journal of Marketing, 31(7/8), 583603.

Baumgarth, C., Merrilees, B., \& Urde, M. (2013). Brand orientation: Past, present, and future. Journal of Marketing Management, 29(9-10), 973-980.

BBC (2016). Kids Company closure: What went wrong? [Online] Available: http://www.bbc.co.uk/news/uk-33788415 (February 1, 2016).

Belk, R. W. (2009). Sharing. Journal of Consumer Research, 36(5), 715-734.

Belk, R. W., \& Llamas, R. (2012). The nature and effects of sharing in consumer behavior. Transformative consumer research for personal and collective well-being, 625-646.

Bénabou, R., \& Tirole, J. (2003). Intrinsic and extrinsic motivation. Review of Economic Studies, 70(244), 489-520.

Benkler, Y. (2004). Sharing nicely: On shareable goods and the emergence of sharing as a modality of economic production. Yale Law Journal, 114, 273.

Bennett, R. (1998). Market orientation among small to medium sized UK charitable organisations: Implications for fund-raising performance. Journal of Nonprofit \& Public Sector Marketing, $6(1), 31-45$.

Bess, G. (1998). A first stage organization life cycle study of six emerging nonprofit organizations in los angeles. Administration in Social Work, 22(4), 35-52.

Betzler, D., \& Gmür, M. (2016). Does fundraising professionalization pay? Nonprofit Management and Leadership, 27(1), 27-42.

Beville, H. M. (1966). The product life cycle theory applied to color television. (MA ), New York University. 
Blader, S. L., \& Tyler, T. R. (2009). Testing and extending the group engagement model: Linkages between social identity, procedural justice, economic outcomes, and extrarole behavior. Journal of Applied Psychology, 94(2), 445-464.

Blau, P. M. (1964). Exchange and power in social life. Piscataway, NJ: Transaction Publishers.

Brexendorf, T. O., Bayus, B., \& Keller, K. L. (2015). Understanding the interplay between brand and innovation management: Findings and future research directions. Journal of the Academy of Marketing Science, 43(5), 548-557.

Brodie, E., Hughes, T., Jochum, V., Miller, S., Ockenden, N., \& Warburton, D. (2011). Pathways through participation: What creates and sustains active citizenship. London, UK: Institute of Volunteering Research/NCVO.

Brodie, R. J. (2017). Commentary on "working consumers: Co-creation of brand identity, consumer identity, and brand community identity”. Journal of Business Research, 70, 430-431.

Bruns $\varnothing$, K., Scholderer, J., \& Grunert, K. G. (2004). Closing the gap between values and behavior-a means-end theory of lifestyle. Journal of Business Research, 57(6), 665-670.

Cabinet-Office. (2017). Community life survey. London, UK: UK Government.

Cameron, K. S., \& Whetten, D. A. (1981). Perceptions of organizational effectiveness over organizational life cycles. Administrative Science Quarterly, 525-544.

Carlos Pinho, J., Paula Rodrigues, A., \& Dibb, S. (2014). The role of corporate culture, market orientation and organisational commitment in organisational performance: The case of non-profit organisations. Journal of Management Development, 33(4), 374-398.

Chad, P. (2014). Organizational change within charities: Improved performance via introduction of market orientation and other strategic orientations. International Review on Public and Nonprofit Marketing, 11(1), 89-113. 
Champniss, G., Wilson, H. N., \& Macdonald, E. K. (2015). Why your customer's social identities matter. Harvard Business Review, 92(1/2), 88-96.

Cherington, P. T. (1924). Some commercial aspects of styles and fashions in the clothing and textile industries. Harvard Business Review, 2(4), 421-433.

Chiang, C. -T., Wei, C. -F., Parker, K. R., \& Davey, B. (2017). Exploring the drivers of customer engagement behaviours in social network brand communities: Towards a customer-learning model. Journal of Marketing Management, 33(17/18), 1443-1464.

Choi, S. (2014). Learning orientation and market orientation as catalysts for innovation in nonprofit organizations. Nonprofit and Voluntary Sector Quarterly, 43(2), 393-413.

Clancy, K., \& Krieg, P. (2004). Product life cycle: A dangerous idea. Brandweek, 45(9), 26.

Clary, E. G., Ridge, R. D., Stukas, A. A., Snyder, M., Copeland, J., Haugen, J., \& Miene, P. (1998). Understanding and assessing the motivations of volunteers: A functional approach. Journal of Personality \& Social Psychology, 74(6), 1516-1530.

Clifford Jr, D. K. (1965). Managing the product life cycle. Management Review, 54(6), 34.

Cox Jr, W. E. (1967). Product life cycles as marketing models. Journal of Business, 40(4), 375-384.

Cyert, R. M., \& March, J. G. (1963). A behavioral theory of the firm. Englewood Cliffs, NI: PrenticeHall.

Dart, R. (2004). Being "business-like" in a nonprofit organization: A grounded and inductive typology. Nonprofit and Voluntary Sector Quarterly, 33(2), 290-310.

Dato-on, M. C., Keller, E. D., \& Shaw, D. (2015). Adapting for-profit branding models to small nonprofit organizations: A theoretical discussion and model proposition Marketing in transition: Scarcity, globalism, \& sustainability (pp. 290-290). USA: Springer. 
de Chernatony, L., \& Riley, F. D. O. (1998). Defining a "brand": Beyond the literature with experts' interpretations. Journal of Marketing Management, 14(4/5), 417-443.

Delre, S. A., Broekhuizen, T. L. J., \& Bijmolt, T. H. A. (2016). The effects of shared consumption on product life cycles and advertising effectiveness: The case of the motion picture market. Journal of Marketing Research (JMR), 53(4), 608-627.

Dessart, L., Veloutsou, C., \& Morgan-Thomas, A. (2016). Capturing consumer engagement: Duality, dimensionality and measurement. Journal of Marketing Management, 32(5-6), 399-426.

Dhalla, N. K., \& Yuspeh, S. (1976). Forget the product life cycle concept. Harvard Business Review, 54(1), 102-112.

Eisend, M., \& Stokburger-Sauer, N. E. (2013). Brand personality: A meta-analytic review of antecedents and consequences. Marketing Letters, 24(3), 205-216.

Emerson, R. M. (1976). Social exchange theory. Annual Review of Sociology, 2(1), 335-362.

Engelen, A., Brettel, M., \& Heinemanr, F. (2010). The antecedents and consequences of a market orientation: The moderating role of organisational life cycles. Journal of Marketing Management, 26(5-6), 515-547.

Field, G. A. (1971). Do products really have life cycles? California Management Review, 14(1), 92-95.

Fournier, S. (1998). Consumers and their brands: Developing relationship theory in consumer research. Journal of Consumer Research, 24(4), 343-373.

Gainer, B., \& Padanyi, P. (2002). Applying the marketing concept to cultural organisations: An empirical study of the relationship between market orientation and performance. International Journal of Nonprofit \& Voluntary Sector Marketing, 7(2), 182.

Gatignon, H., \& Xuereb, J. -M. (1997). Strategic orientation of the firm and new product performance. Journal of Marketing Research, 77-90. 
Gebhardt, G., Carpenter, G., \& Sherry Jr, J. (2006). Creating a market orientation: A longitudinal, multifirm, grounded analysis of cultural transformations. Journal of Marketing, 70(4), 37-55.

Gephart, R. P. (2004). Qualitative research and the Academy of Management Journal. Academy of Management Journal, 47(4), 454-462.

Giesler, M. (2006). Consumer gift systems. Journal of Consumer Research, 33(2), 283-290.

Goodyear, M. (1993). Reviewing the concept of brands and branding. Marketing and Research Today, 21(2), 75-75.

Guo, B. (2006). Charity for profit? Exploring factors associated with the commercialization of human service nonprofits. Nonprofit and Voluntary Sector Quarterly, 35(1), 123-138.

Hankinson, P., Lomax, W., \& Hand, C. (2007). The time factor in re-branding organizations: Its effects on staff knowledge, attitudes and behaviour in uk charities. Journal of Product \& Brand Management, 16(4/5), 236-246.

Hasenfeld, Y., \& Schmid, H. (1989). The life cycle of human service organizations. Administration in Social Work, 13(3-4), 243-269.

Hicks, J. (1956). A revision of demand theory. Oxford, UK: Clarendon Press.

Hollebeek, L. D., Conduit, J., \& Brodie, R. J. (2016). Strategic drivers, anticipated and unanticipated outcomes of customer engagement, Editorial, Journal of Marketing Management, 32(5-6), 393398.

Hoyer, W. D., MacInnis, D. J., \& Pieters, R. (2012). Consumer Behaviour (Sixth ed.). Boston, MA: South-Western Cengage Learning.

Hubert, M., \& Kenning, P. (2008). A current overview of consumer neuroscience. Journal of Consumer Behaviour, 7(4-5), 272-292. 
Hwang, H., \& Powell, W. W. (2009). The rationalization of charity: The influences of professionalism in the nonprofit sector. Administrative Science Quarterly, 54(2), 268-298.

Jaworski, B. J., \& Kohli, A. K. (1993). Market orientation: Antecedents and consequences. Journal of Marketing, 57(3), 53.

Johnson Dretsch, H., \& Kirmani, A. (2014). Why are some brand co-creation activities more effective than others?: The effects of brand knowledge potential and self-brand connection on brand engagement intentions. NA-Advances in Consumer Research Volume 42.

Khodakarami, F., Petersen, J. A., \& Venkatesan, R. (2015). Developing donor relationships: The role of the breadth of giving. Journal of Marketing, 79(4), 77-93.

Kohli, A. K., \& Jaworski, B. J. (1990). Market orientation: The construct, research propositions, and managerial implications. Journal of Marketing, 54(2), 1-18.

Koroloff, N. M., \& Briggs, H. E. (1996). The life cycle of family advocacy organizations. Administration in Social Work, 20(4), 23-42.

Kotler, P. R. (1968). Computer simulation in the analysis of new-product decisions. In F. M. Bass, C. W. King \& E. A. Pessemier (Eds.), Applications of the sciences in marketing management. New York, NY: John Wiley \& Sons Ltd.

Kumar, V. (2010). Customer relationship management. Wiley International Encyclopedia of Marketing (Vol. 1). New York, NY: John Wiley and Sons Ltd.

Kylander, N., \& Stone, C. (2012). The role of brand in the nonprofit sector. Stanford Social Innovation Review, 10(2), 35-41.

Leckie, C., Nyadzayo, M. W., \& Johnson, L. W. (2016). Antecedents of consumer brand engagement and brand loyalty. Journal of Marketing Management, 32(5-6), 558-578. 
Lee, Z. (2013). Rebranding in brand-oriented organisations: Exploring tensions in the nonprofit sector. Journal of Marketing Management, 29(9-10), 1124-1142.

Lester, D. L. (2004). Organisational life cycle stage and strategy: Must they match? International Journal of Management \& Decision Making, 5(2/3), 135-143.

Levitt, T. (1965). Exploit the product life cycle. Harvard Business Review, 43(6),81-94.

Li, R. (1996). A theory of conceptual intelligence: Thinking, learning, creativity, and giftedness. Westport, CT: Praeger Publishers.

Li, Y. -Z., He, T. -L., Song, Y. -R., Yang, Z., \& Zhou, R. -T. (2018). Factors impacting donors' intention to donate to charitable crowd-funding projects in China: A utaut-based model. Information, Communication \& Society, 21(3), 404-415.

Liao, M. -N., Foreman, S., \& Sargeant, A. (2001). Market versus societal orientation in the nonprofit context. International Journal of Nonprofit \& Voluntary Sector Marketing, 6(3), 254.

Macedo, I. M., \& Carlos Pinho, J. (2006). The relationship between resource dependence and market orientation: The specific case of nonprofit organisations. European Journal of Marketing, 40(56), 533-553.

MacInnis, D. J. (2011). A framework for conceptual contributions in marketing. Journal of Marketing, 75(4), 136-154.

Maier, F., Meyer, M., \& Steinbereithner, M. (2016). Nonprofit organizations becoming business-like a systematic review. Nonprofit and Voluntary Sector Quarterly, 45(1), 64-86.

Malhotra, N. K. (1988). Self concept and product choice: An integrated perspective. Journal of Economic Psychology, 9(1), 1-28. 
Malthouse, E. C., Calder, B. J., Kim, S. J., \& Vandenbosch, M. (2016). Evidence that user-generated content that produces engagement increases purchase behaviours. Journal of Marketing Management, 32(5-6), 427-444.

Maslowska, E., Malthouse, E. C., \& Collinger, T. (2016). The customer engagement ecosystem. Journal of Marketing Management, 32(5-6), 469-501.

Mathur, A. (1996). Older adults' motivations for gift giving to charitable organizations: An exchange theory perspective. Psychology \& Marketing, 13(1), 107-123.

Mauss, M. (1967). The Gift, trans. Ian Cunnison. New York, NY : W.W. Norton \& Company.

McDonald, R. E. (2007). An investigation of innovation in nonprofit organizations: The role of organizational mission. Nonprofit and Voluntary Sector Quarterly, 36(2), 256-281.

McEnally, M., \& De Chernatony, L. (1999). The evolving nature of branding: Consumer and managerial considerations. Academy of Marketing Science Review, 2(1), 1-16.

McFall, J. (1969). Priority patterns and consumer behavior. Journal of Marketing, 33(4), 50-55.

Merrilees, B., \& Miller, D. (2008). Principles of corporate rebranding. European Journal of Marketing, 42(5/6), 537-552.

Michel, G., \& Rieunier, S. (2012). Nonprofit brand image and typicality influences on charitable giving. Journal of Business Research, 65(5), 701-707.

Miller, D., \& Friesen, P. H. (1983). Successful and unsuccessful phases of the corporate life cycle. Organization Studies, 4(4), 339-356.

Miller, D., Merrilees, B., \& Yakimova, R. (2014). Corporate rebranding: An integrative review of major enablers and barriers to the rebranding process. International Journal of Management Reviews, 16(3), 265-289. 
Mintzberg, H. (1984). Power and organization life cycles. Academy of Management Review, 9(2), 207224.

Moon, Y. (2005). Break free from the product life cycle. Harvard Business Review, 83(5), 86-94.

Mowen, J. C., \& Sujan, H. (2005). Volunteer behavior: A hierarchical model approach for investigating its trait and functional motive antecedents. Journal of Consumer Psychology 15(2), 170-182.

Narver, J. C., \& Slater, S. F. (1990). The effect of a market orientation on business profitability. Journal of Marketing, 20-35.

NCVO. (2018). UK Civil Society Almanac. London, UK: National Council for Voluntary Organisations.

O'Brien, S. (2018). How the 'no’ campaign fell apart. The Sunday Times. [Online] Available: https://www.thetimes.co.uk/article/how-the-no-campaign-fell-apart-zrrgtlx2f (June 3, 2018).

Omoto, A. M., \& Snyder, M. (1995). Sustained helping without obligation: Motivation, longevity of service, and perceived attitude change among aids volunteers. Journal of Personality \& Social Psychology, 68(4), 671-686.

Padanyi, P., \& Gainer, B. (2004). Market orientation in the nonprofit sector: Taking multiple constituencies into consideration. Journal of Marketing Theory and Practice, 12(2), 43-58.

Park, C. W., Jaworski, B. J., \& Maclnnis, D. J. (1986). Strategic brand concept-image management. Journal of Marketing, 135-145.

Phelps, R., Adams, R., \& Bessant, J. (2007). Life cycles of growing organizations: A review with implications for knowledge and learning. International Journal of Management Reviews, 9(1), 130.

Piliavin, I. M., Rodin, J., \& Piliavin, J. A. (1969). Good samaritanism: An underground phenomenon? Journal of Personality and Social Psychology, 13(4), 289. 
Piliavin, J. A., \& Hong-Wen, C. (1990). Altruism: A review of recent theory and tesearch. Annual Review of Sociology, 16(1), 27-65.

Pledger, R. (1981). The organizational life cycle: Issues in the creation, transformation, and decline of organizations. Academy of Management Review, 6(3), 518-520.

Polli, R., \& Cook, V. (1969). Validity of the product life cycle. Journal of Business, 42(4), 385-400.

Potter, A. (2011). The authenticity hoax: Why the" real" things we seek don't make us happy. New York, NY: Harper Perennial.

Randle, M., \& Dolnicar, S. (2011). Self-congruity and volunteering: A multi-organisation comparison. European Journal of Marketing, 45(5), 739-758.

Ricketts, A. (2017). Two charities for deaf people set to merge. [Online] Available: https://www.thirdsector.co.uk/two-charities-deaf-people-set-merge/management/article/1440057 (July 20, 2017).

Ross, B., Halliday, S., France, C., Merrilees, B., \& Miller, D. (2015). Customer brand co-creation: A conceptual model. Marketing Intelligence \& Planning, 33(6), 848-864.

Rothman, L. I. (1967). Measurement and description of product life cycles. (MBA), University of Pennsylvania.

Sanders, M. L. (2015). Being nonprofit-like in a market economy: Understanding the mission-market tension in nonprofit organizing. Nonprofit and Voluntary Sector Quarterly, 44(2), 205-222.

Sargeant, A. (2009). Marketing management for nonprofit organizations (Third ed.). Oxford, UK: Oxford University Press.

Sargeant, A., \& Lee, S. (2004). Trust and relationship commitment in the united kingdom voluntary sector: Determinants of donor behavior. Psychology \& Marketing, 21(8), 613-635. 
Schembri, S., \& Latimer, L. (2016). Online brand communities: Constructing and co-constructing brand culture. Journal of Marketing Management, 32(7-8), 628-651.

Scheuing, E. E. (1969). The product life cycles as an aid in strategy decisions. Management International Review, 9(4/5), 111-124.

SCIE. (2007). Practice example 16: Royal national institute of the blind (rnib). The participation of adult service users, including older people, in developing social care. [Online] Available: http://www.scie.org.uk

Shoham, A., Ruvio, A., Vigoda-Gadot, E., \& Schwabsky, N. (2006). Market orientations in the nonprofit and voluntary sector: A meta-analysis of their relationships with organizational performance. Nonprofit and Voluntary Sector Quarterly, 35(3), 453-476.

Singh, A. (2017). Two years on from Kid's Company, it's time to decide if charities are worth saving. [Online] Available: https://www.theguardian.com/voluntary-sector-network/2017/aug/08/kidscompany-is-charity-worth-saving (August 8, 2017).

Sirgy, M. J. (1982). Self-concept in consumer behavior: A critical review. Journal of Consumer Research, 9(3), 287-300.

Slater, S. F., \& Narver, J. C. (1994). Does competitive environment moderate the market orientationperformance relationship? Journal of Marketing, 46-55.

Smith, R. (2015). Asking the difficult questions. [Online] Available: http://www.cloresocialleadership.org.uk/Rachael-Smith-research (February 1, 2015).

Stobaugh, R. B. J. (1968). The product life cycle, U.S. Exports, and international investments. (PhD), Harvard Business School.

Storey, C., \& Hughes, M. (2013). The relative impact of culture, strategic orientation and capability on new service development performance. European Journal of Marketing, 47(5/6), 833-856. 
Stride, H. (2006). An investigation into the values dimensions of branding: Implications for the charity sector. International Journal of Nonprofit \& Voluntary Sector Marketing, 11(2), 115-124.

Tapp, A., Lindsay, G., \& Sorrell, R. (1999). Towards a branding framework for cause-, funding-and need-oriented charities. Journal of Marketing Communications, 5(1), 39-50.

Tidwell, M. V. (2005). A social identity model of prosocial behaviors within nonprofit organizations. Nonprofit Management and Leadership, 15(4), 449-467.

Titmuss, R. M. (1971). The gift relationship. New York, NY: Pantheon.

Urde, M., Baumgarth, C., \& Merrilees, B. (2013). Brand orientation and market orientation—from alternatives to synergy. Journal of Business Research, 66(1), 13-20.

Vaughan, G. (1997). For-giving: A feminist criticism of exchange (Vol. 53). Austin, TX: Plain View Press.

Venable, B. T., Rose, G. M., Bush, V. D., \& Gilbert, F. W. (2005). The role of brand personality in charitable giving: An assessment and validation. Journal of the Academy of Marketing Science, 33(3), 295-312.

Vernon, R. (1966). The product life cycle. Quarterly Journal of Economics, 66, 121-140.

Wilson, J., \& Musick, M. (1997). Who cares? Toward an integrated theory of volunteer work. American Sociological Review, 694-713.

Wong, H. -K., \& Ellis, P. D. (2007). Is market orientation affected by the product life cycle? Journal of World Business, 42(2), 145-156.

Woolf, N. (2016). Remember the ice bucket challenge? It just funded an ALS breakthrough. [Online] Available: https://www.theguardian.com/society/2016/jul/26/ice-bucket-challenge-als-charitygene-discovery (July 27, 2016) 
Wymer Jr, W. W., \& Rundle-Thiele, S. (2016). Supporter loyalty conceptualization, measurement, and outcomes. Nonprofit and Voluntary Sector Quarterly, 45(1), 172-191.

Wymer Jr, W. W., \& Samu, S. (2002). Volunteer service as symbolic consumption: Gender and occupational differences in volunteering. Journal of Marketing Management, 18(9/10), 971-989.

Yadav, M. S. (2010). The decline of conceptual articles and implications for knowledge development. Journal of Marketing, 74(1), 1-19.

Yadav, M. S. (2014). Enhancing theory development in marketing. AMS Review, 4(1), 1-4.

Zaltman, G. (1983). Presidential address. Advances in Consumer Research, 10(1), 1-5.

Zerounian, P., Shing, J., \& Hanni, K. D. (2011). Assessing nonprofit networks prior to funding: Tools for foundations to determine life cycle phase and function. Foundation Review, 3(1/2), 43-58.

Zhang, X., Han, X., Liu, X., Liu, R., \& Leng, J. (2015). The pricing of product and value-added service under information asymmetry: A product life cycle perspective. International Journal of Production Research, 53(1), 25-40. 